\title{
Empirical Study on the Application of CALL in Writing Classroom
}

http://dx.doi.org/10.3991/ijet.v10i1.4297

\author{
Cao Fenglong \\ Benbu Medical College, Benbu, China
}

\begin{abstract}
As technology increasingly takes center stage of our lives, there are compelling reasons for incorporating technologies into the classroom. The prevailing of CALL (Computer Assisted Language Learning) has greatly changed the traditional teaching mode and added new contents into the existing teaching materials. As a significant skill for EFL (English as a Foreign Language) learners, there are abundant researches in writing, yet little documentation exists on the application of CALL in writing classroom. This paper reviews relevant theories and research, and then investigates three research questions by an empirical study. The results gained have some pedagogical implications in the future.
\end{abstract}

Index Terms-Accuracy, CALL, Non-intelligence, Writing

\section{INTRODUCTION}

The technical encroachment of information technology conveys impact on the English language learning as it seems to boost students' motivation, which leads increased usage and proficiency. CALL (Computer Assisted Language Learning) is defined by various theorists and practitioners, of which the following are considered precise and salient: Levy once defined it as "the search for and study of applications of the computer in language teaching and learning"[1], but unfortunately, is less specific and targeted; Beatty considers: "Given the breadth of what may go on in computer-assisted language learning (CALL), a definition of CALL that accommodates its changing nature is any process in which a learner uses a computer and, as a result, improves his or her language"[2], which appropriately adapted to the development of computer science and language teaching; to the author, the definition by Gamper and Knapp is the most up-to-date and comprehensive one, "a research field which explores the use of computational methods and techniques as well as new media for language learning and teaching"[3]. One of the advantages of applying computer science in language teaching was demonstrated by the famous American behaviorist Skinner "Even in a small classroom the teacher usually knows that he is going too slowly for some students and too fast for others. Those who could go faster are penalized, and those who should go slower are poorly taught and unnecessarily punished by criticism and failure. Machine instruction would permit each student to proceed at his own rate."[4].

The history of CALL dates back to the 1950s, when it was the experimental stage because of the limited computer hardware and technology [5]. Since the 80s, CALL has been gradually introduced to high schools and universities in Europe, when computer technology became more accessible to both individuals and schools. The years since 90 s up to now have witnessed the blooming of computer science applied in language teaching and learning, which inspires much valuable research findings. Since its prevailing in the 1980s, CALL has roused a kaleidoscope of research in its specific realm, which fell into studies using quantitative and/or qualitative methodologies on computer use in second/foreign language learning, such as potentials of computer technology in second language learning, software tools to support specific skills acquisition, importance of applying pedagogy and design principles, etc.[6], moreover, many researchers also delved into the application of CALL into different language skills, such as listening, speaking, reading and writing, etc.

There will be a huge potential for the development of CALL in the future, especially the application of internet will provide more options to language teaching. First of all, internet offers rich variety of resources to language teaching, which diversifies the contents as well as forms of teaching. These resources will more and more take the form of audios and video, thus more direct and acceptable, spurring the students to learn with enthusiasm. Secondly, there will be more and more online tools for language teaching, besides the existing "email" and "BBS", nowadays there are more forums such as blog, micro-blog, etc, which will make the process of learning free from space and time limitations. However, how will these new forms of technology being applied in language teaching and learning with efficacy and efficiency remains a question less touched, which the trend and direction of future research.

Writing, as defined by Wikipedia [7], is the representation of language in a textual medium through the use of a set of signs or symbols (known as a writing system). It is also a key component for foreign language learners as an important language output, reflecting one's proficiency in learning a foreign language. As one of students' productive skills, mirrors their command of a foreign language to a great extent, and it is not only believed that writing is a kind of knowledge, but also the ongoing reflections of students' developing understanding of ideas, which is claimed as a socially constructed act as well as a cognitive one. Hyland (2003, xiii) [8] once justified why students should write: On one hand, the ability to communicate ideas and information effectively through the global digital network is crucially dependent on good writing skills; on the other hand, a further strengthening of the status of writing within applied linguistics has come from the expanded knowledge base on the nature of written texts and writing processes that have been developed by scholars in such fields as composition studies, second language writing, genre theory, and contrastive rhetoric. Therefore, it is 
conspicuous that writing receives researchers' attention and has remained a research topic for long. What is more, within the realm of second and foreign language teaching and learning, the study on writing has come to assume a much more central and dominant position than before. The past 20 years have been for writing teachers a time of intense fermentation, reflection, and innovation. "The reasons are many, resting partly in social and demographics change and partly in a professional paradigm shift generated by research into how writers write." [9]

However, the research in combination of in CALL and writing, especially in the context of Chinese foreign language writing classroom are not so frequent and common as the above-mentioned paradigms. This essay, in the following part, will investigate the benefits and potentials of using CALL in a writing classroom.

\section{THEORETICAL UNDERPINNINGS OF CALL}

The research of CALL is based on certain theories, such as linguistic, computer science, multi-media technology as well as web technology theory, therefore, is a highly comprehensive and overlapping discipline. According to Jia (2007), the following theories back up the application of CALL in foreign language teaching classrooms: behaviorism, cognitivism, as well as communicative language teaching theory.

Behaviorism focuses on one particular view of learning: a change in external behavior achieved through a large amount of repetition of desired actions, the reward of good habits and the discouragement of bad habits. In the classroom this view of learning led to a great deal of repetitive actions, praise for correct outcomes and immediate correction of mistakes. In the field of language learning this type of teaching was called the audio-lingual method, characterized by the whole class using choral chanting of key phrases, dialogues and immediate correction.

Cognitivism is the theory that humans generate knowledge and meaning through sequential development of an individual's cognitive abilities, such as the mental processes of recognize, recall, analyze, reflect, apply, create, understand, and evaluate. The Cognitivists' learning process is adoptive learning of techniques, procedures, organization, and structure to develop internal cognitive structure that strengthens synapses in the brain. The learner requires assistance to develop prior knowledge and integrate new knowledge. The educators' role is pedagogical in that the instructor must develop conceptual knowledge by managing the content of learning activities. This theory relates to early stages of learning where the learner solves well defined problems through a series of stages.

Communicative language teaching (CLT), or the communicative approach, is an approach to language teaching that emphasizes interaction as both the means and the ultimate goal of study. According to Nunan, here are five features of this teaching mode:

1. An emphasis on learning to communicate through interaction in the target language.

2. The introduction of authentic texts into the learning situation.

3. The provision of opportunities for learners to focus, not only on language but also on the learning process itself.
4. An enhancement of the learner's own personal experiences as important contributing elements to classroom learning.

5. An attempt to link classroom language learning with language activities outside the classroom. [10]

The development of linguistic theory roughly experiences from behaviorism in the 1940-1950s, coginitivism in the $1960-1970$ s to communicative since the $80 \mathrm{~s}$. So is the evolvement of CALL. Crook applied three metaphors to illustrate the three stages: a tutorial metaphor (computer-as-a-tutor), a construction metaphor (computer-as-apupil), and a tool box metaphor (computer-as-a-tool). (Crook, 1994) [11]

The behaviorist considers computers as tutors, thus, the language teaching software designed are based upon drill and practice programs, mainly used to practice grammar, vocabulary, as well as evaluation. Since behaviorism believes repetition mechanically is the presupposition of language learning, computer to language learning is what tutor is to students. The advantage of this CALL mode is that it emphasizes the preciseness of language, and it is easy to design, which suits language learning at primary stages. The limitation of this mode, however, lies in that it fails to arouse students' enthusiasm, who are treated merely as passive learners.

The cognitive theory regards computers as pupils, which successfully transfers the target from teaching software to students. During this period, preciseness of language learning is no longer that stressed, instead, it encourages the students to acquire new knowledge through self exploration. The design of teaching software is not limited as the previous drill and practice program, it takes the new form such as problem solving and hypothesis testing. Experts and researchers believe that students under this teaching mode, have gained more autonomy and controlling ability towards the computer, therefore, experienced less anxiety during the process. Opposite arguments are aired because they worry the role of teachers under CALL and that there is little cooperation between peers since each one is busy interacting with his/her computer.

When it comes to communicative language teaching, it applies computers as tools. It aims to liberate learners from human-computer communication, making computers as tools to enhance the interaction between students and the teacher, students and students. Students are encouraged to achieve meaningful interaction in authentic discourse communities. Warschauer concludes four characteristics of internet applied in language teaching and learning:

1. Informational representation through multi-linear strands linked electronically,

2. Integration of graphics, audio, and audiovisual information together with text,

3. Rapid global access, and

4. Ease and low cost of international publication. (Warschauer,2000) [12]

All in all, the above-mentioned theories all contribute to the development of CALL and each has its own advantages and disadvantages. When it comes to real practice, researcher should choose a suitable theory according to the real situation, or integrate these three ones. 


\section{Methodology}

Language learning is a multi-faceted social and cultural phenomenon, even more so when it involves new technologies that promote a variety of social interactions (Kern \& Warschauer, 2000) [13]. Therefore, studies employing both qualitative as well as quantitative measures are needed to explain the complex interaction of social, cultural and individual factors that shape the language learning process in a computer assisted environment. The following research, generally speaking, applies both quantitative as well qualitative methodologies, to make sure the results relatively balanced and trustworthy. In detail, the research questions are as follows:

1. Is CALL facilitative in improving students' writing?

2. Which aspect of the writing (accuracy, content, structure, etc.) is most improved by CALL?

3. What do the students benefit from CALL in writing classroom?

Based on the relevant literature reviewed in the preceding chapter, these three research questions lead to three hypotheses correspondingly:

1. CALL will act efficiently in students' writing classroom.

2. Of different aspects of the writing, CALL works most efficiently in improving one's accuracy.

3. Students benefit a lot in the application of CALL in a writing classroom, such as their motivation in foreign language writing, critical thinking ability, team work and cooperation awareness, etc.

\section{RESEARCH DESIGN}

We randomly selected 100 sophomores from different departments at a medical college in Anhui Province, which were recruited from four separate paralleled nonEnglish major classes. The ages of these students ranged from 18 to 21 , with the average of 19.33 . Most of them had been learning English for at least 7 years successively and learners at this level have learned enough to write simple essays and have intermediate proficiency.

These participants were randomly assigned to two treatment options - the experimental group having computer assisted writing lessons and the control group received none CALL activities during the whole process, each group being distributed with 50 students. The study lasted for seven weeks, including a mini lecture, five writing tasks and a questionnaire to complete.

During the whole process, the experimental group attended writing classes in the multi-media classroom, each student writing on a computer with access to certain software, such as the online dictionary, grammar check system, and LAN (Local Area Network), which enables students have interaction with their peers and the teacher, also they had the opportunity to read model compositions in the mini database prepared by the teacher. The control group, however, will have writing lessons in the traditional way-the teacher gives instructions related to the writing task, the students do their writing tasks independently without any assistance or communication with their peers or teacher. Both groups have a mini lecture presented by the teacher on certain writing techniques at the very beginning of the experiment to make sure each student knows how to write a cohesive and coherent composition.
TABLE I.

\begin{tabular}{l|l}
\hline Day 1 & A mini lecture on certain writing techniques \\
\hline Day 8 & Writing task 1 \\
\hline Day 15 & Writing task 2 \\
\hline Day 22 & Writing task 3 \\
\hline Day 29 & Writing task 4 \\
\hline Day 36 & Writing task 5 \\
\hline Day 43 & Questionnaire completion (to the experimental group only) \\
\hline
\end{tabular}

From the second week to the sixth week, each group was required to write five writing tasks successively. After each composition, teachers scored and gave feedback on each composition. To make sure the objectivity of the results, the teacher invited three peer teachers scoring (full mark: 100 points) on the writing and produced the average as the final data. On the completion of the writing task, a questionnaire was presented to each participant in the experimental group, after which collected questionnaires were numbered and classified, and were then analyzed by SPSS (Statistical Package for the Social Sciences) 19.0 to obtain descriptive statistics with respect to learners' perceptions of writing classes assisted by computer. The procedure of the data collection session is presented in Table I.

\section{RESUlTS}

So far, the review of relevant theories and studies, the research questions and hypotheses, the methodology and research design have been illustrated in the previous parts. In this part, the data elicited from the five writing tasks and questionnaires are analyzed by SPSS and the results are presented based on each research questions, judging whether the hypotheses are tested or rejected.

Research question one: the efficacy of CALL in writing classes

The first research question investigates whether the practice of CALL is conductive to the EFL learners in their writing classes, that is to say, whether experimental group outperformed those in the control group in the writing tasks.

The descriptive statistics, as shown in Table II and Fig. 1 , including means, number of subjects and standard deviation of the two groups respectively, provides a straightforward picture of the participants' performances.

TABLE II.

DESCRIPTIVE STATISTICS FOR THE EXPERIMENTAL GROUP AND THE CONTROL GROUP

\begin{tabular}{c|c|c|c|c}
\hline \multicolumn{1}{c}{ Group } & $\begin{array}{c}\text { Writing } \\
\text { task }\end{array}$ & $\mathbf{N}$ & Mean & Std. deviation \\
\hline \multirow{4}{*}{$\begin{array}{l}\text { The experi- } \\
\text { mental group }\end{array}$} & Task 1 & 50 & 73.25 & 10.23 \\
\cline { 2 - 5 } & Task 2 & 50 & 73.97 & 10.97 \\
\cline { 2 - 5 } & Task 3 & 50 & 74.63 & 11.33 \\
\cline { 2 - 5 } & Task 4 & 50 & 76.44 & 12.76 \\
\cline { 2 - 5 } & Task 5 & 50 & 78.12 & 11.65 \\
\hline \multirow{4}{*}{$\begin{array}{l}\text { The control } \\
\text { group }\end{array}$} & Task 1 & 50 & 73.33 & 12.87 \\
\cline { 2 - 5 } & Task 2 & 50 & 73.20 & 11.41 \\
\cline { 2 - 5 } & Task 3 & 50 & 71.45 & 10.65 \\
\cline { 2 - 5 } & Task 4 & 50 & 72.14 & 12.52 \\
\cline { 2 - 5 } & Task 5 & 50 & 73.28 & 13.77 \\
\hline
\end{tabular}




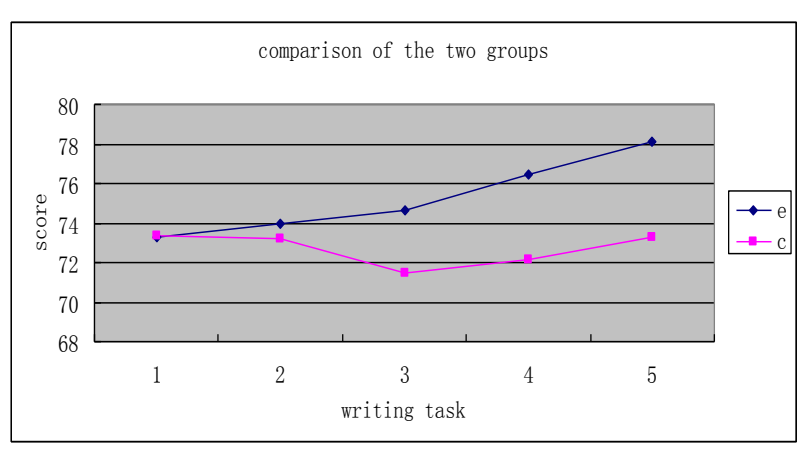

Figure 1.

As far as the experimental group is concerned, there is trend of increase in the mean score (from 73.25, 73.97, $74.63,76.44$ to 78.12 ), which reveals that students in this group benefited and improved a lot in the CALL writing class. However, in the control group where students received no computer assisted activities, no obvious improvement was demonstrated during the tasks. Also viewed from the Table II is the standard deviations of the two groups, which are more or less the same (SDe1,2,3,4,5=10.23,10.97,11.33,12.76,11.65;

SDc $1,2,3,4,5=12.87,11.41,10.65,12.52,13,77)$, ensuring the stability of the data and the effects of extreme data not attributable to the treatments were actually eliminated.

Research question two: aspect most improved by CALL

The second research question probes into which aspect of writing, namely, accuracy, content and structure, is affected by CALL to the greatest extent. The investigation is made only among the experimental group. That is to say, are there any differences of efficacy among the three aspects? In the experiment, the teacher divided the score of each composition into three aspects: $40 \%$ of accuracy, $30 \%$ of content and another $30 \%$ for structure.

The descriptive statistics, as shown in Table III and Fig. 2 , including mean score of each aspect and standard deviations, helps to explore the question with more clarity.

From Table III and figure 2, it can be concluded that of the three aspects in a composition, accuracy score increases with the passage of time while there are no obvious improvements as far as content and structure are concerned. No major change is seen from the standard deviation, which reviews the stability of the statistics.

Research question three: students' general attitudes toward CALL in writing

The third research question was answered by the analysis of students' questionnaires, which consists both objective and open-ended questions. In the first part, students are required to use number 1-5 to indicate their degree of agreement on each statement. In the open-ended questions, students write their comments and understandings of CALL in writing classes.

From Table IV, it can be viewed that most of the students in the experimental group agree that the application of CALL in writing classes indeed increased their nonintelligence factors, such as motivation in learning English, ability to learn, critical thinking ability, cooperation awareness and communicative competence. To further explore the reason why they made such choices, we choose excerpts of their answer in the open-ended questions part.

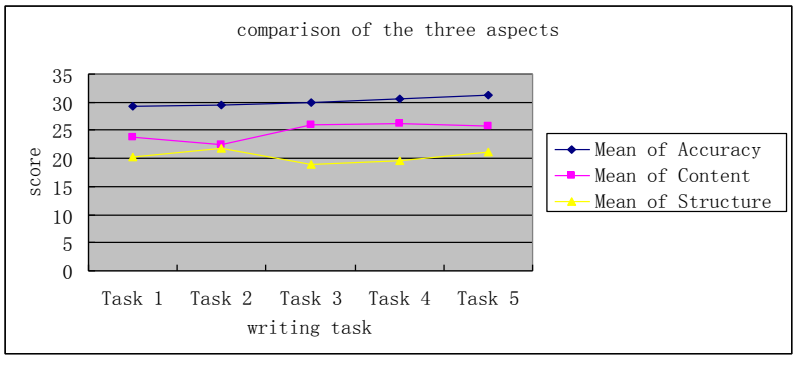

Figure 2. Comparison of the three aspects

TABLE III.

DESCRIPTIVE STATISTICS OF EACH ASPECT IN THE EXPERIMENTAL GROUP

\begin{tabular}{c|c|c|c|c}
\hline $\begin{array}{c}\text { Writing } \\
\text { task }\end{array}$ & $\begin{array}{c}\text { Mean of } \\
\text { accuracy }\end{array}$ & $\begin{array}{c}\text { Mean of } \\
\text { content }\end{array}$ & $\begin{array}{c}\text { Mean of } \\
\text { structure }\end{array}$ & $\begin{array}{c}\text { Std. } \\
\text { deviation }\end{array}$ \\
\hline Task 1 & 29.30 & 23.74 & 20.21 & 3.64 \\
\hline Task 2 & 29.58 & 22.52 & 21.87 & 4.12 \\
\hline Task 3 & 29.85 & 25.95 & 18.83 & 3.75 \\
\hline Task 4 & 30.58 & 26.21 & 19.65 & 3.61 \\
\hline Task 5 & 31.25 & 25.69 & 21.18 & 4.09 \\
\hline
\end{tabular}

TABLE IV.

STUDENTS' GENERAL ATTITUDES TOWARD CALL IN WRITING

\begin{tabular}{l|l|c|c}
\hline \multicolumn{1}{c|}{ Benefits } & \multicolumn{1}{|c|}{ Degree } & Frequency & Percent \\
\hline \multirow{2}{*}{$\begin{array}{l}\text { Increased moti- } \\
\text { vation in learn- } \\
\text { ing English }\end{array}$} & Agree (4\&5) & 42 & $84.00 \%$ \\
\cline { 2 - 4 } & Disagree (1\&2) & 3 & $6.00 \%$ \\
\cline { 2 - 4 } & Mild attitude (3) & 5 & $10.00 \%$ \\
\hline \multirow{2}{*}{$\begin{array}{l}\text { Increased ability } \\
\text { to learn }\end{array}$} & Agree (4\&5) & 47 & $94.00 \%$ \\
\cline { 2 - 4 } & Disagree (1\&2) & 3 & $6.00 \%$ \\
\cline { 2 - 4 } $\begin{array}{l}\text { Increased criti- } \\
\text { cal thinking } \\
\text { ability }\end{array}$ & Mild attitude (3) & 0 & $0.00 \%$ \\
\cline { 2 - 4 } & Agree (4\&5) & 44 & $88.00 \%$ \\
\cline { 2 - 4 } $\begin{array}{l}\text { Increased coop- } \\
\text { eration aware- } \\
\text { ness }\end{array}$ & Misagree (1\&2) & 4 & $8.00 \%$ \\
\cline { 2 - 4 } & Agree (4\&5) & 2 & $4.00 \%$ \\
\cline { 2 - 4 } & Disagree (1\&2) & 2 & $82.00 \%$ \\
\hline \multirow{2}{*}{$\begin{array}{l}\text { Increased com- } \\
\text { municative } \\
\text { competence }\end{array}$} & Mild attitude (3) & 7 & $14.00 \%$ \\
\cline { 2 - 4 } & Disagree (1\&2) & 0 & $98.00 \%$ \\
\cline { 2 - 4 } & Mild attitude (3) & 1 & $0.00 \%$ \\
\hline
\end{tabular}

Student A: I think this method of practicing writing, I mean, to have a computer with many useful software to help me finish the composition, is really useful. In the past, I (did) not like English writing, but now, I think it is full of fun. I really expect to have writing classes like this in the future.

Student B: In the past, I always rely (relied) on the teacher, whatever she said in class, I just keep taking notes. Things are different now! I read the model composition on the computer, I also look (up) in the online dictionary when I do not know the English translation (equivalence) of a Chinese word.

Student C: I find there is a problem. The autocorrection function in the computer is not always correct. Sometimes, many words underlined by the computer (suggesting there is an error) are actually not wrong at all. So I do not trust it all the time.

Student D: In this kind of writing class, I can discuss with my classmates by Email or online chatting software 
on how to write the composition and also help to correct the mistakes we have.

Student E: I am a shy student, I dare not communicate with my teacher in the past. But now, any time I find a problem and need help, I send an email to my teacher in class, and soon she will give me reply.

\section{DISCUSSION}

With the statistics collected in the experiment, all of the three hypotheses have been tested. With regard to the first research question, findings echo with the previous studies in the efficacy of CALL used in writing classes [14] [15][16][17]. In consideration of the flaws and limitations of the previous research that few had explored in depth on the efficacy of CALL from different aspects of writing, the author found that CALL in writing classes helps the students in improving their accuracy most. The reason maybe lies in the fact that most software in the computer for CALL is helpful in correcting students' errors, especially the grammatical ones, and that at the intermediate level, students are liable to focus on the accuracy part while giving feedback on their own or others' drafts. In the questionnaire part, the author found CALL in also facilitative in improving students' non-intelligence factors [18][19][20][21]: such as motivation to learn, ability to learn, team work spirit, communicative competence and critical thinking awareness, etc.

The results gained from the experiment may shed light on future research and also give some pedagogical implications to the writing classroom, for example, although CALL in writing is facilitative in accuracy, the improvements in content and structure are not obvious currently, which is a question worth thinking.

\section{CONCLUSION}

In this paper, the author first reviews the general history of CALL, the categories of research on CALL in the past decades, pinpoints the importance of writing in EFL teaching and learning, and clarifies the research orientation in this paper: the combination of CALL and writing, then illustrates the theories that back up the application of CALL, followed by the methodology that penetrates the whole research is introduced, namely, quantitative plus qualitative, later, the structure and procedure of the research is portrayed to the reader, followed by the data analysis and research findings. In a nutshell, the significance of this research lies in that it explores the efficacy of CALL in writing classes, some findings echoing with the previous ones, some beyond the existing discoveries, also the reason of these benefits are also discussed. Results of this study may provide a basis for further research and directions for a larger study. Incorporating the stages of writing process approach in a collaborative learning environment via CALL is a practical strategy to be implemented. Hopefully, more and more studies in computer mediated communication will generate more insights, knowledge and information that will lead to a broader understanding of the paradigms in network language teaching and learning.

\section{REFERENCES}

[1] M. Levy, CALL: context and conceptualization. Oxford: Oxford University Press, p.1; pp.13-46, 1997.
[2] K. Beatty, "Teaching and researching computer assisted language learning," in Applied Linguistics in Action Series, Harlow: Pearson Education, p7; p33; p35, 2003.

[3] J. Gamper, J. Knapp, "A review of intelligent call systems," Computer Assisted Language Learning, vol. 15, no. 4, pp. 329342, 2012. http://dx.doi.org/10.1076/call.15.4.329.8270

[4] B. Skinner, The Technology of Teaching. New York: AppletonCentury-Crofts, p.30, 1968.

[5] Jia Guodong, Computer Assisted Language Learning-Theory and Practice. Beijing: Higher Education Press, p.5,2007.

[6] M. Liu, L.Graham, S.Lee, "A look at the research on computerbased technology use in second language learning: review of literature from 1990-2000," Journal of Research on Technology in Education, vol. 34, no. 3, pp. 21, 2002. http://dx.doi.org/10.1080/15391523.2002.10782348

[7] Web: http://en.wikipedia.org/wiki/Writing

[8] K. Hyland, Second Language Writing. Cambridge: Cambridge University Press, p.xiii, 2003. http://dx.doi.org/10.1017/CBO9780511667251.002

[9] M. Hairston, "The winds of change: Thomas Kuhn and the Revolution in the Teaching of Writing," College Composition and Communication, vol. 33, no. 1, pp. 76-88, 1982. http://dx.doi.org/10.2307/357846

[10] D. Nunan, Language Teaching Methodology: A Textbook for Teachers. London: Prentice Hall, 1991.

[11] C. Crook, Computers and the Collaborative Experience of Learning. London: Routledge, 1994.

[12] M. Warschauer \& R. Kern, Network-based Language Teaching: Concepts and Practice. Cambridge: Cambridge University Press, p12, 2000. http://dx.doi.org/10.1017/CBO9781139524735

[13] R. Kern \& M. Warschauer, "Introduction: Theory and practice of network-based language teaching," In M. Warschauer \& R. Kern (Eds.), Network-based Language Teaching. Cambridge: Cambridge University Press, pp. 1-19, 2000. http://dx.doi.org/10.1017/CBO9781139524735.003

[14] E. New, "Computer-aided writing in French as a foreign language: a qualitative and quantitative look at the process of revision," The Modern Language Journal, vol. 83, no. 1, pp. 81-97, 1999. http://dx.doi.org/10.1111/0026-7902.00007

[15] H.F. Shang, "An exploratory study of e-mail application on FL writing performace," Computer Assisted Language Learning, vol. $20, \quad$ no. $1, \quad$ pp. 79-96, 2007. http://dx.doi.org/10.1080/09588220601118479

[16] T. Michio, "Multimedia as a means to enhance feedback," Computer Assisted Language Learning, vol. 17, no. 3/4, pp. 377-402, 2004.

[17] Gu Peiya, CALL: Theory and Practice. Shanghai: Fudan University Press, 2006, p.2.

[18] D.Wagener, "Promoting independent learning skills using video on digital language laboratories," Computer Assisted Language Learning, vol. 19, no. 4/5, pp. 279-286, 2012.

[19] J.Vinther, "Cognitive processes at work in CALL," Computer Assisted Language Learning, vol. 18, no. 4, pp. 251-271, 2005. http://dx.doi.org/10.1080/09588220500280388

[20] Hou Jingjing, “Optimizing college students' non-intelligence factors in the computer-aided college English teaching environment," Computer Assisted Foreign Language Education, vol. 1, no. 119 , pp. 53-56, 2008.

[21] He xuzhi, "Communicative theory and foreign language writing teaching," Hunan Social Sciences, vol. 1, no. 2, pp. 12-23, 2001.

\section{AUTHOR}

Cao Fenglong is with Benbu Medical College, Benbu 233030 China (e-mail: caofenglong@163.com).

Submitted 01 December 2014. Published as resubmitted by the authors 21 February 2015. 